\title{
The Dead Bodies of Bobruisk, Belarus 1941-45
}

Therkel Stræde University of Southern Denmark

therkel@sdu.dk

\begin{abstract}
This paper traces the massacres of Jews and Soviet prisoners of war in November 1941 in the city of Bobruisk, Eastern Belarus. Sparked by a current memorial at one of the killing sites, the author examines the historic events of the killings themselves and presents a micro level analysis of the various techniques for murdering and disposing of such large numbers of victims. A contrast will be shown between the types of actions applied to the victims by the German army, SS, police personnel and other local collaborators, reflecting an imposed racial hierarchisation even after their death.
\end{abstract}

Key words: Bobruisk, Belarus, Nazi atrocities, Jews, POWs, killing techniques, disposal of corpses, Sonderaktion 1005

In November 1941, the city of Bobruisk in Eastern Belarus was scene to massacres of Jews and Soviet prisoners-of-war (POWs), committed by the German army, SS and police personnel along with local collaborators. A simple memorial at one of the killing sites in the nearby village Kamenka displaying human remains lead the author of this article - a Danish historian investigating the role and crimes of Danish SS volunteers in the region - to ponder over the actual killings that took place at this spot, and the vicious system developed by the Nazis to involve their victims as involuntary aides in the process of their own destruction and the disposal of the victims' bodies - an aspect of the Nazi crimes to which Soviet and postSoviet Belarussian memorial culture paid no attention. ${ }^{1}$ Starting at the Kamenka memorial site, the article describes the history of the massacres perpetrated by the Nazis on large numbers of Jews and Soviet POWs during November 1941. The Bobruisk massacres demonstrate the improvised, trial-and-error-like character of the development of German mass killing techniques. At massacres, the perpetrators facilitated 'internal transportation' tasks by forcing Jewish victims to move towards their death on their own feet, and to some extent even arrange themselves in the mass graves before being killed. To the German perpetrators, however, killing was not just killing. There was from the first moment a contrast between the methods used for disposal of the bodies of the Jews and those of Soviet POWs 
which indicates that even between two groups both considered to be 'subhuman' enemies of the German state and race, there was a racial hierarchisation at work as a conscious factor in the decisions made by the perpetrators regarding the detailed techniques used at the killing field level. This appears again to have been the case in late 1943 when the Germans attempted at disposing of the victims' buried corpses by exhuming and burning them to ashes and camouflaging the sites of mass graves in the course of the Sonderaktion 1005. Thus, technological aspects of the micro level analysis provide insights into the general problem of the perpetrators' motivation and their possible guilty conscience towards the two main categories of victims of the Nazi 'Eastern campaign', and throw new light on the use of human remains in the design of the Kamenka memorial.

\section{The Kamenka memorial}

After having occupied Belarus, the Germans quickly made its Western areas part of what they called Reichskommissariat Ostland. As the Wehrmacht was unable to push its Eastern front as far to the East as planned, nor reach the early, victorious conclusion Hitler was counting on, the Eastern part of Belarus was never transferred to civilian rule; all through the German occupation from 1941-44 it remained part of the Army Group Center Rear Area, Rückwärtiges Heeresgebiet Mitte. One of its major cities and an important junction of main roads and railway lines was Bobruisk on the West bank of the river Berezina, today a city of some 250,000 inhabitants. Shortly outside Bobruisk, the memorial area and monuments depicted are located at the edge of a forest next to a village called Kamenka. ${ }^{2}$ Difficult to reach and with no signs pointing to its existence, the memorial consists of a fenced-in grass-clad area with scattered fir trees and two stone monuments. A taller monument on the left was erected by a citizens' commission in 1964 and renewed in the 1970s after having been vandalised. ${ }^{3}$ According to its inscription, it commemorates 'Thousands of men, women, children and prisoners-of-war shot and killed by the German fascists during the Great Patriotic War 1941-45'. This includes people who were killed at this very site as well as in the entire city of Bobruisk. Its aesthetics with the golden lettering on black polished marble, fivepointed star and laurel of victory belong to traditional Soviet World War II memorial culture, as did its predecessor.

The monument on its right is more recent, and was erected after the break-down of the Soviet Union. It is a roughly cut rock of light grey granite with a Magen David engraving, and explicitly commemorates the Jews of Bobruisk murdered by the Germans. Whereas the younger monument in terms of colour and aesthetics resembles many for the Israeli Holocaust, the older monument as well as the entire layout of the memorial area around it is clearly Soviet. There is a short paved path edged by flower beds leading from the entrance of the fenced memorial site to the monument where two persons can walk alongside each other. And at the end of the path, there is a clear marking of an elevated 'sacred area' with a symbolic entrance: the visitor passes between two quasi coffin-shaped concrete structures flanked by 'sacrificial bowls'. These do not carry ever-burning flames, which is the immediate 
association, considering their aesthetics, but evergreen bushes - another symbol of eternity. From where the 'sacred area' begins, stairs take the visitor up a small mound to the central monument. The mound is grass-clad like the rest of the larger memorial site which is surrounded by a painted metal fence made in Soviet times out of scrap iron. On closer inspection the visitor will notice between the rows of fir trees long, low mounds in the grass; these symbolise the mass graves and mark their approximate location.

Visitors are scarce at this place. Whereas the 'Great Patriotic War' and the Belarussian partisans' contribution to the defeat of the Germans is being commemorated as widely in today's Republic of Belarus as it was during Communism, there is only scant recognition of the hundreds of thousands of Belarussian Jews who were murdered by the Germans and their brought-in and local collaborators. Apart from small local Jewish communities and occasional visitors from abroad, few seem to care about commemorating the loss under horrible conditions of what was once a substantial element of Belarussian society.

The fenced-in area in Kamenka is more or less identical with the killing site where the first major massacre of Jews in Bobruisk took place after the Germans occupied the city. It was conducted on 5-7 November 1941. Members of the German Einsatzkommando 8 and Police Battalion 316 aided by mainly Ukrainianstaffed auxiliary police murdered Jewish men, women and children - a total of 5,281 , as the SS officer in charge proudly reported to the Einsatzgruppe B headquarters after the action. ${ }^{5}$

A map sketch drawn in January 1945 by a Soviet war crimes commission that investigated the atrocities committed by the Germans during their three years' rule in Bobruisk shows the location of the mass graves 400 metres off the main road between Bobruisk and Slutsk next to the village of Kamenka. ${ }^{6}$ The map is not accurate and not all buildings were marked. Between the main road and the mass graves a rather large complex of several buildings was located that served and still serves as a disabled people's home. This is most likely why the Germans picked this place to serve as a killing site; on one hand, it was close to the city and near a larger paved road, which was important to the logistics of the operation, on the other hand it was out of sight and hearing range from the city, and due to its being a disabled people's home this place was already considered a 'tainted' by the Germans as well as by locals. According to Nazi racial ideology, the handicapped - at least the substantial portion of those whose disability was considered hereditary - were seen as 'useless eaters', people of lesser value and a threat to German racial purity. ${ }^{7}$ The Soviets, on their side, aimed at perfectioning mankind, would simply store disabled persons away, so their stigmatisation was also common-place amongst the locals; a place populated by 'misfits' would be avoided by most, and thus be a perfect place to 'hide' the mass graves.

In January 1945, a local resident, Pavel Fomichenko, questioned by the Soviet war crimes commission, described the killing site as follows:

I know of a site of mass murder of innocent Soviet citizens. The site is nine kilometers from the city of Bobruysk, 400 meters right of the road. For a few days before 


\section{Therkel Stræde}

the killings, Russian prisoners of war dug three pits forty to fifty meters long, three meters wide and up to three meters deep. After a few days, the Germans brought the innocent citizens of Bobruysk there in closed trucks, and killed them on the spot. On the third day of the murders, I visited the site and saw the pits filled with bodies. ${ }^{8}$

'Innocent Soviet citizens' was in Soviet memory culture the general formula for civilian victims of Nazi atrocities. It was deliberately used in a universalising sense to avoid referring to the victims' ethnic or other identity and acknowledging the fact that a large proportion of them - especially in the Western parts of the occupied Soviet territory - were Jews. ${ }^{9}$

The November 5-7 massacre was not the first mass killing the Germans carried out in Bobruisk. Previously, on 5 August 1941, it seems, Sonderkommando $7 b-\mathrm{a}$ forerunner of Einsatzkommando 8 - conducted one on the same spot. The victims were 250-800 Jewish able-bodied men (testimony differs) who had been selected on the pretext of having to do out-of-town forced labour. ${ }^{10}$ They were killed according to the German tactics of doing away at an early stage with members of the Jewish elite and young able-bodied males who would be likely to head resistance to the German objectives. The mass grave from this first killing operation -6 metres long, 4 metres wide and 3 metres deep - was located a bit further into the Kamenka forest area, and is marked on the map sketch, too, although with exaggerated dimensions.

\section{The 5-7 November 1941 massacre of Jews}

'Aktion judenrein' was the name the Germans used for the 5-7 November massacre. ${ }^{11}$ The leading Einsatzkommando-officers in Bobruisk were eager to demonstrate efficiency, and boldly claimed to have 'cleansed the city of Jews'. But only a few weeks later, they realised that the operation had left more Jews alive in Bobruisk than had been killed. So a second large-scale massacre was conducted at a different location on 30-31 December 1941 which killed another 5-7,000 Jews and left only a few hundred Jewish craftsmen as well as some hidden Jews alive in Bobruisk, a city which in 1939 was home to more than 26,000 Jews, equalling one third of the total population. ${ }^{12}$

The 'Aktion judenrein' started on 5 November with the concentration and briefing of the police forces as well as the requisitioning of most trucks in the city. Locals warned the Jews in the ghetto that had been established a few weeks earlier, and some Jews escaped or went into hiding. Early next morning German and local police searched the ghetto and drove the Jews into the street and to an assembly point at the premises of a nearby dairy factory. Here a selection was conducted; a group of skilled labourers and other so-called 'specialists' and their families were taken aside. Everybody else was packed into trucks and taken to Kamenka to be shot.

Prisoners from the Dulag 131 transit camp for Soviet POWs, located at the compound of Bobruisk's vast nineteenth century citadel, had been brought in to dig the mass graves. Forcing Jews to do the job, as was often seen, would have alerted the 
Jews in the ghetto to what was about to happen, and might have provoked attempts at resistance or mass escape. The Germans considered Soviet POWs as well-suited as they ranked little above the Jews in the Nazi racial hierarchy, and they would be strictly isolated from contact with others so the impending massacre would not be given away. Secrecy was an important precondition for the smooth operation of such large-scale killings. However, the burial pits were left open for several days, meaning that news of them reached the city and alarmed at least some of the Jewish community.

\section{German mass shooting techniques in the 'Eastern Areas'}

When the German police forces moved into Soviet territory in June 1941 they did not have a standard procedure for mass executions like this one, although the mass shooting of civilians and POWs had already been exercised during the Polish campaign in $1939 .{ }^{13}$ No detailed orders specifying the organisational and technical details of such massacres were handed out, and it is obvious from actual variations in the ways they were carried out that the methodology of mass killing was to a large extent left up to the commanders of the authorities and units to decide. ${ }^{14}$ Eventually, though, the Einsatzgruppen, police battalions and other units involved in the wholesale killing of the Jews of the Rückwärtiges Heeresgebiet Mitte developed - through a ghastly process of trial-and-error during the first months of the 'Barbarossa' campaign - a liking for two slightly different mass shooting techniques which both involved the soon-to-be-killed victims as involuntary co-workers of their own destruction. ${ }^{15}$

Since the killing of 2,500 human beings or more a day was no easy task, containment was an important issue in several different respects; 1 ) The Jews had to be contained physically during concentration in order to prevent runaways from stirring up solidarity, maybe even protest from the local population. The Germans registered at an early stage that many Belarussians - different from in Ukraine and the Baltic countries - did not consider Jews any different from the rest of the population, so when the Germans tried to instigate pogroms during the first weeks of the occupation, Belarussians did not join in. ${ }^{16}$ 2) Physical containment at the killing site was important to make sure that no-one escaped their destiny, as the overall objective of the Jews' total annihilation was - according to most historians - clear at least from August/September 1941 (some would say already from the planning phase of the 'Barbarossa' campaign). ${ }^{17}$ 3) Psychological containment of the perpetrators aesthetically or in some cases even ethically caused unease at the killing of innocent civilians, as well as the Angst provoked by the 'wild' and dantesque aspects of the mass shootings, was important in order to keep the perpetrators motivated and fit for action. Among other things, the close, partly bodily, contact with the victims would represent a serious strain on the killers, so if the victims were made to walk and carry each other to their death, this would relieve the killers of immediate physical contact, of touching them - unless, of course, they wanted to. In practice, however, distance proved difficult to maintain. Consequently, on the first afternoon of the Kamenka massacre, killing had to be 


\section{Therkel Stræde}

interrupted because some shooters were losing their self-control and had to be replaced. ${ }^{18}$

In the course of the first months of German rule in the occupied Soviet territories, two slightly different techniques of the mass shootings of Jews emerged and became used on a regular basis, in the following to be named Techniques No. 1 and 2. According to Technique No. 1, the victims were killed inside the burial pit. They would be forced to enter the dug-out mass grave by steps or a chute that had been carved into its side, or to jump the three metres down. The pit itself would provide efficient physical containment of the victims, and escapes could easily be prevented by a few guards or the shooters themselves. Quite a lot of violence was however required to make the victims comply and enter the pit since it was all too obvious to them that their death was unescapable once they were in the pit. They would then have to lie down on the bare earth in rows with their faces down, and shooters positioned at the rim of the pit or inside it would shoot them from behind, thus providing a measure of psychological containment since the technique permitted the perpetrators to largely avoid eye-contact with their victims. When a row was completed, a thin layer of dirt was shovelled onto the murdered, and the next victims would lie down on top of the newly murdered, their bodies often still warm and some still alive. The shooting was done by pistols, rifles and submachine guns. Those Jews who did not move eagerly enough towards the killing pit were made to speed up by boot-kicks and blows with rifle butts and bayonets, and those who could not were simply thrown into the pits, including infants and children; often the Germans would penetrate children with bayonets or smash their heads first. Many victims were injured by blows and cuts or simply by jumping into the pits before they were killed, the agony of this adding to their disorientation and despair.

Technique No. 2 differed from No. 1 in that the victims were not brought into the burial pit before being killed; they were shot standing at the edge of it, thus allowing for the use of machineguns. In Kamenka at least two armoured vehicles participated in the shooting using their board-guns. The impact of the shot aided by gravity - and by boot-kicks in case a victim was left swaying or kneeling at the rim of the pit - made sure the victims landed in the burial pit. This procedure would make for shorter intervals between the salvos. The victims' stumbling descent into the pit and passage over the bodies of the already shot cost time and called for incidents of agony and protest which the perpetrators could only 'solve' by additional hands-on violence which again could easily further slow the process. Technique No. 2 omitted this practice but the killed would fall unorderly and fill up only one side of the pit, meaning a number of strong Jews had to be positioned inside the pit in order to relocate the bodies and arrange them in an orderly manner. In the interest of saving space, the dead were sometimes packed 'the sardine way' (Sardinenpackung, i.e. alternating with the head and feet to one side). Technique No. 2 was speedier but also somewhat riskier to the perpetrators and passers-by, as stray bullets would travel far across the pit and way into the landscape, whereas when using Technique No. 1 the mass grave itself would catch the bullets that missed the target or passed through the victims' bodies. The fact that both techniques were used during the Kamenka killings underlines the improvisational nature of Nazi killing technology development. 
Disposal was the key theme of the Corpses of Mass Violence conference in Paris, September 2012 at which this paper was first presented, and it is therefore unavoidable to delve into these horrifying details and thus commit the faux-pas of talking technically about an unimaginable human disaster like the mass murder of 5,281 Jews. But doing so provides some insight into the 'messages' the perpetrators were sending by the way in which they organised the killing, and the hints they provide us with as to their view of the victims and thus ideological motivations. In the case of the Einsatzgruppen killings in Bobruisk - and many other places in the occupied Soviet territories during 1941-42 - the actual killing and disposal of the murdered was conceived and organised as an entirely integrated process. This becomes very clear when comparing the 'Aktion judenrein' with a massacre that took place the very next day, 8 November 1941, in the same city, namely in the Dulag 131 camp for Soviet POWs, partly conducted by the same German police units, this time aided by regular Wehrmacht troops with very different methods of killing and disposal of the victims' bodies. I will later elaborate on this massacre.

Three weeks before the 'Aktion judenrein' in Bobruisk, Police Battalion 316 had used Technique No. 1 ('shooting-in-the-pit') to murder 3,726 Jews in a similar operation in Mogiljov, a district capital some 100 kilometres north-east of Bobruisk, on 17-19 October 1941. The technique was also demonstrated to Heinrich Himmler at a mass shooting of 279 Jews in Mogiljov on 23 October which according to eye-witnesses made the Reichsführer-SS und Chef der Polizei sick and caused him to order that a killing method urgently be developed that would diminish the strain on the perpetrators by securing more distance between them and their victims and strengthen containment physically as well as psychologically. ${ }^{19}$ This event started a hectic experimentation with methods for killing large numbers of people and the rational disposal of their bodies, that would eventually lead to the removal of a major part of the mass killings from improvised on-site shootings to centralised and more or less isolated contained areas and the construction of fordist-style annihilation camps that eventually developed into the huge factorylike gaschamber and crematoria-complexes of Auschwitz-Birkenau. ${ }^{20}$

Surely Himmler was not the only one to be sickened by the 'in-pit shooting' that confronted him with agonising scenes and forced the perpetrators to frequent use of ultra-violence to make the process flow, as Jews were not simply walking to their death as 'sheep to the slaughter'. While a ghastly process of technological innovation unseen in the history of Mankind began, including experimentation with large-scale killing by way of poison gas as well as explosives, the clearing of ghettos, seen as urgent to clear the entire Eastern Belarussian territory of Jews by the end of 1941, continued by means of the established techniques. So three weeks after the Mogiljev killings, the men from Police Battalion 316 were in Bobruisk, where according to witness testimony they used both techniques. ${ }^{21}$

Any killing technique posed an unimaginable strain on the victims. Not only did they have to face an unjust and much too premature death at the hands of cruel murderers and witness extreme brutality as they proceeded towards it, but they were also directly made into co-workers of their own annihilation. They had to undress, the stronger helping the children, sick and elderly, and pre-sort garments 


\section{Therkel Stræde}

into orderly piles so that they could easily be taken for recycling; they had to walk to their death on their own feet, the stronger again aiding or carrying the weak, thus saving the perpetrators most of the effort of handling and moving the bodies around after death themselves. As the following example shows, this integration of the killing and disposal-of-the-bodies process represented a substantial rationalisation and was used particularly for the killing of Jews.

\section{The 8 November 1941 massacre of Soviet prisoners-of-war}

The Nazis had a preference for launching their attacks on 'enemies' of the German race and state on days that carried a symbolic meaning to the victims. So it was no coincidence that they chose the 1941 anniversary of the Bolshevik October Revolution to conduct another massacre in Bobruisk, this time inside the Dulag 131 Camp for Soviet POWs which was at that time the largest POW camp on the Eastern front with 60,000 prisoners in November $1941 .^{22}$

On 8 November 1941, a fire broke out - probably laid by the Germans - in a huge, overcrowded five-storey barracks building inside the Dulag on the citadel compound. Machineguns had been put into position beforehand so that the prisoners who fled into the open area in front of the building - partly in flames - were immediately gunned down. Here the number of victims is uncertain, but it probably exceeds 4,000 on this single day. Subsequently, the dead bodies, or at least some of them, were stripped of clothes to be given to other prisoners and buried elsewhere in the citadel area.

The Yad Vashem photo archive in Jerusalem holds a number of photos depicting the victims of the massacre as well as the everyday mass death by starvation and random violence by guards that occurred in the Dulag 131 POW camp of Bobruisk during Autumn 1941. Originally the photos were ascribed to the Kamenka massacre of the Jews of Bobruisk, but the fact that they display only dead bodies of men of military age, and that almost all of them are in a state of extreme emaciation, convinced the Yad Vashem archivists that the photos actually depict victims of the POW camp. The victims of the Kamenka massacre were Jews of both sexes and all ages including a large number of children, and extreme emaciation would only have occurred in a few cases as the ghetto of Bobruisk from where they came had only existed for one month; and, as mentioned, in Kamenka the Jews were shot in or at the rim of the mass graves.

One photo shows some fifty or more dead bodies that have been thrown disorderly and partly on top of each other over a large outdoor area covered with grass and mud. ${ }^{23}$ It clearly depicts only a segment of an even larger area covered with corpses, most of which are entirely naked and display signs of extreme emaciation. In some cases, faces can be seen, all bearded, as well as wounds. At the top end some fuel barrels, truck wheels and other military waste indicate that the field of corpses is located next to an army waste dump of sorts. The picture invites the conclusion that the bodies have been thrown there by other Soviet POWs in a similar state of emaciation, and the disorder indicates that this happened in great haste such as after a major killing operation. This all fits well into the situation in the 
Bobruisk complex of POW camps during the last months of 1941. Mortality was extremely high due to starvation, epidemics, untreated battle wounds and random violence by the guards who were instructed to use their guns at the slightest sign of insubordination. ${ }^{24}$ Most prisoners were in the state that we know from German concentration camps as Muselmann, as were the victims of the 8 November massacre which took place in and outside the building where POWs deemed unfit for work had been concentrated.

A second photo from the same series has obviously been taken close to the first spot and displays more or less the same topographic character. ${ }^{25}$ Minor parts of the barren ground are covered by snow, likely following a thaw. Here, the corpses most naked and some partly or entirely dressed in uniform-style garments - have been piled quite orderly into two long rows of at least twenty metres each with three to five corpses on top of each other. A group of six POWs in Soviet military coats gather around a two wheel horse carriage with no horse, probably used for transportation of the bodies. Another three POWs are seen in the far background performing individual tasks, the nature of which is not obvious from the photo. The photo most probably depicts an intermediate stage between the immediate disposal of the bodies and their burial in mass graves.

A third photo depicts the burial itself. ${ }^{26}$ A larger number of similarly dressed POWs - some wearing fur hats commonly used by members of the Red Army - gather at the rim of a 3-4 metres deep and 2-3 metres wide mass grave that stretches 5-10 metres or more from the far end of the photo towards the camera standpoint. Dead bodies - most of them naked and showing signs of extreme emaciation - are being tossed into the mass grave quite disorderly, but inside it two POWs are just taking what seems to be a short break from the task of rearranging the corpses at the command of another POW located at the opposite rim of the grave. In the far background, another band of POWs is employed possibly with a similar activity, and even further a moat-like embankment and two-storey or taller brick buildings are seen that appear to be part of the nineteenth century fortress where the Bobruisk POW camp complex was located.

The photos demonstrate the horrendous disrespect for human lives that the Germans demonstrated towards the Soviet POWs during the 1941 Barbarossa campaign where members of the Red Army were systematically brought to death in huge numbers adding up to a total of three million out of five million prisoners taken. ${ }^{27}$ In Bobruisk, by 20 November, 14,777 had already died, mainly by starvation, out of a total of 158,000 who had passed through that camp from July to November, and the main Bobruisk camp was a transit camp where prisoners were meant to stay for only a few weeks at a maximum. These photos depict a segment of these victims, most likely including victims of the 8 November massacre. They may have been taken in connection with the mid-November 1941 inspection that was conducted by Wehrmacht Oberst Otto Marschall, but its exact provenance and the route of the photos to Jerusalem is so far unknown. They do, however, allow for a technical and quite cynical observation: the photos demonstrate that the handling and disposal of such large numbers of dead bodies involved a substantial work effort, had to be organised and could take a lot of time. 


\section{The victims' involvement in their own killing}

In the German camps for Soviet POWs, time and labour was, however, abundant and secrecy was not an issue since the prisoners - at this time of the Soviet campaign - were all destined to die. As for the mass killings of Jews, the situation was different. They took place at sites that had been picked ad-hoc and primarily for their convenient location close to larger concentrations of Jews. These killing sites were located inside civil society, so to speak; the remnants had to be treated and the sites camouflaged so that 'grass would quickly grow over them' in order for delicate Germans and the locals who were to willingly collaborate with them not to feel disturbed by their existence. Here, considering the large amount of mass killings that were conducted in the almost successful attempt to 'cleanse' Eastern Belarus of Jews by the end of 1941, the time factor was important. First there was the sudden stroke-like unleashing of the 'Aktion', then the swift disappearance of any trace of the crime, which would allow the Germans and locals to proceed with their everyday life as if the Jews had never been there.

Victims involuntarily contributed to saving time and speeding up the killing operations as they performed - under extreme pressure - a substantial part of the 'internal transportation' of this 'production of corpses' by their own feet and hands, and by the solidarity they mobilised for those who could not take care of themselves. Thus the victims, without intention, assisted in their own annihilation and the perpetrators knew how to get them to comply. This quite thoroughly rationalised system of field mass-killings made the place of death identical to the place of the dead bodies' disposal, and this was one major reason why the Einsatzgruppen, Police Battalions and other SS and Wehrmacht units aided by collaborators were able to kill as many as eighty per cent of the 240,000 Jews who had not managed to escape from Eastern Belarus as the Germans moved in, in the course of less than six months.

\section{Disposal of disposal: the Sonderaktion 1005 in Bobruisk, 1943}

On 7 November 1941 in Kamenka, after closing the mass graves the Germans had armoured vehicles and belt tractors drive across the area in order to bulldoze the graves and make sure that buried victims who had not been deadly hit by the shooting - or not hit at all - would not survive. Witnesses were convinced that when they saw the earth above the mass graves tremble for several days after the shootings this was because some victims were still alive or rather not quite dead inside the graves, although the phenomenon was more likely caused by gases developed by the natural process of corporal decay. Apart from the twelve year old Yosef Kogan, no victims are known to have dug themselves out of the Kamenka mass graves. ${ }^{28}$

The story of the Kamenka killing site does not however end with the fall of night on 7 November 1941. But apart from a few minor group killings later on, the site seems to have become out of use after the 'Aktion judenrein'. Later, mass shootings of Jews, Soviet POWs, inmates of the Bobruisk prisons and others took place at different locations, primarily near the village of Jeloviki at the northern edge of the 
city. To the Germans, Jeloviki on the main road to Minsk would count as equally tainted, as it was located next to the city's Jewish cemetery from tsarist times. ${ }^{29}$

But two years after the November 1941 massacres, in October 1943 it seems, a unit of Paul Blobel's Sonderaktion 1005 moved into Bobruisk..$^{30}$ SS-Standartenführer (colonel) Paul Blobel's special squad was organised in 1942 to find ways to dispose of the large numbers of dead bodies in the annihilation camps, that had evolved out of the Himmler order to develop alternatives to the field mass shootings that had proven so strenuous to the killers. Blobel's units, however, soon found their task expanded to the erasure of mass graves that were strewn all over the occupied Polish and Soviet territories. The 1005 units would unearth the corpses and cremate them on pyres, crush or grind whichever skeleton parts that were not destroyed by fire and dispose of the ashes in rivers, lakes or forests or in some cases rebury them in the former mass graves; finally, they would camouflage the former killing sites by levelling the soil, sowing grass and planting trees and bushes, and in the case of the annihilation camp Bełżec they even erected a farmer's cottage on the site of the former camp. ${ }^{31}$ Slave labourers, usually taken from local Gestapo prisons or POW camps, would have to perform the agonising work under strenuous conditions, and would normally be killed, as the 1005-unit moved on to the next place.

After having worked first in Poland, then in Ukraine, Aktion 1005 units moved on to Belarus in early Autumn 1943. Former Sonderkommando and Einsatzkommando staff were recruited into them and, consequently, Dr. Friedrich Seekel was in charge of the unit that was temporarily stationed in Bobruisk, who had commanded parts of the Einsatzkommando 8 that had covered the area two years earlier. ${ }^{32}$ The unit emptied the Kamenka mass graves, but little is known about the specifics. According to a survivor, the 'cleaning-up' of a similar site in the nearby town of Osaritji, where some 4,000 Jews had been buried in three massgraves, took 280 slave labourers guarded by sixty-eight German policemen 5-6 days, and the burning of the corpses alone lasted two days. ${ }^{33}$ The slave labourers who handled the corpses would be transported, sometimes also accommodated, in gas vans, i.e. mobile gaschambers that had in 1941-42 been used primarily to kill psychiatric patients, disabled people and orphans; now they were used on a regular basis to kill most of the slave labourers just before the Aktion 1005 unit moved on to its next destination.

Leon Weliczker-Wells, a slave labourer who managed to run away from an Aktion 1005 unit, has described the incineration technique that was used with some variations by the units belonging to this operation throughout the Germanoccupied Soviet and Polish territories during 1943-44. ${ }^{34}$ Slave labourers would open the mass graves and exhume the dead bodies of the primarily Jewish victims. Upon a grill made out of a truck chassis or a roster of railway rails, placed over a horizontal ventilation duct dug into the earth, they would build a pyre of corpses alternating with firewood logs that would be soaked in whatever fuel or solvent was at hand and brought to burn. Hundreds to a few thousand corpses would be incinerated at a time, the process lasting 2-3 whole days, and bone remains would adjacently be crushed by using home-made jumping jacks or in some cases a professional bone mill taken from a nearby slaughterhouse. Finally, the ashes would be 


\section{Therkel Stræde}

spread out in a nearby forest or moor, lake or river - if the officer in charge did not order the reburial of the ashes in the original mass graves which would save time and allow the Aktion 1005 unit to move quickly on to the next location of mass murder. Under the pyres, a blackish substance of tar, bodily fluids, ashes and dirt would conglomerate to a stone-like consistency, and such material was later found in Bobruisk at the Kamenka site.

\section{The relocation of disposed-of bodies, 1964}

In 1964, during excavations to the foundations of what is today the Belshina Tire factory in Jeloviki/Bobruisk, remnants of what turned out to be several mass graves were discovered. At this site the Germans had conducted a number of mass killings, mainly of Soviet POWs. A local Jewish man, Meïr Zeliger, managed to gather a group of volunteers and get permission to exhume the bodily remains and move the skulls and bones to Kamenka where a modest memorial had been established early after the war. Here they were reburied in the mass graves where Jews had been buried in 1941, and which Aktion 1005 had emptied in 1943 and refilled with their ashes. ${ }^{35}$ A picture from a private photo album of his own shows Meïr Zeliger in the middle of this reburial work that was barely tolerated, and only much later recognised, by the Communist authorities. ${ }^{36}$

When comparing this photo with the photo of the Kamenka memorial, one is confronted with a paradox and a riddle: what was the true mission of Aktion 1005 in 1943/44? In Jeloviki where mainly, if not only non-Jews - members of the local resistance and Soviet POWs in numbers similar to the Kamenka shootings - were killed and buried over the course of some two and a half years, the Germans left the mass-graves untouched. In Kamenka, where practically only Jews were buried, a laborious effort was made to erase the traces. It could not be that the Aktion 1005 team was forced by the development of the war to interrupt its assignment and leave unfinished business behind, since more than half a year was still to pass from the Aktion 1005 unit's stay in Bobruisk until the battle and subsequent liberation of the city in late June 1944; so no need for the Aktion 1005 unit to hastily move on can be detected that could explain why the disposal of the disposed of bodies was only carried out at one of Bobruisk city's mass execution sites. Although only scarce material is available about the Aktion 1005, it seems obvious that the removal of Jewish corpses seems to have had priority over the removal of nonJewish corpses. In that case, this fact can easily be interpreted as a tacit admission by the perpetrators that the killing of Jewish civilians including women, children and the elderly was a unique crime and one that lacked justification - the opposite to the killing of enemy soldiers and civilians who supported them, that is those victims already singled out for reprisal killings by orders from the Wehrmacht High Command before the attack on the Soviet Union (those which have since the 1945-46 Nuremberg trial been known as 'the criminal orders'). The killing of these victims would be considered as justified and thus less criminal and in need of concealment by the perpetrators and administrators who tried to cover their deeds. 


\section{The Kamenka memorial revisited}

Turning to the Kamenka memorial site once again, a closer look at the 'older' monument reveals that the coffin-like structures that mark the entrance to the 'sacred' area in fact display human remains ${ }^{37}$ What one sees are not rocks, but lumps of the tar-like residue from under the pyres on which the bodies of the Jews who had been murdered in November 1941 were burnt by the 1005-team two years later. When I first realised this, I felt deeply alienated that human remains of the murdered victims were left unburied without protection from weather-caused deterioration, and placed on display for the general public, just as I had felt in 1990 when I visited the memorial at the former Sobibor annihilation site and was confronted with glass coffins located at the edge of the symbolic central ash-mound displaying skulls and bones that had been found in the area. It is possible, however, to view the grim display of human remains as markers of the symbolic victory over Nazism, as they may be interpreted to say: the Nazis tried to erase all traces of their major crime and thus make it undone from the point of view of history, make the Jews disappear from the surface of the earth; but they did not succeed. The victims, represented by their human remains, are still here, and so are, as we can see from the younger monument in Kamenka, the Jews.

\section{Notes}

1 This article is primarily based on research into the German occupational policy and atrocities in the region of Bobruisk, Belarus 1941-44 conducted with curator Dennis Larsen of the Danish National Museum (Frøslev Concentration Camp Museum), published in D. Larsen \& T. Stræde, Bobruisk, Hviderusland 1941-44. Frikorps Danmarks skole i vold (Copenhagen, Gyldendal, 2014); For important background information, see Y. Slutzky (ed.), Bobroysk: Sefer Zikaron li-Kehilat Bobroysk u-Veneteha (Memorial Book of Bobruisk and its surroundings) (Tel Aviv, Former Residents of Bobruisk in Israel and the USA, 1967), English translation at http://www.jewishgen.org/yizkor/bobruisk/bysktoc1.html (accessed 28 December 2012), especially p. 214ff; M. J. Imbachkau, Pamyat' Babruysk (Minsk, Vyshebnaja Shkola, 1995), p. 347-439; C. Gerlach, Kalkulierte Morde: Die deutsche Wirtschafts- und Vernichtungspolitik in Weissrussland 1941 bis 1944 (Hamburg, Hamburger Edition, 1999), especially p.503ff, 774ff; C. Hartmann, Wehrmacht im Ostkrieg. Front und militärisches Hinterland 1941/42 (Munich, Oldenbourg, 2009), p.568ff, 635ff; J. Hasenclever, Wehrmacht un Besatzungspolitik in der Sowjetunion. Die Befehlshaber der rückwärtigen Heeresgebiete 1941-1943 (Paderborn, Schöningh, 2010), p. 472ff; D. Pohl, Die Herrschaft der Wehrmacht. Deutsche Militärbesatzung und einheimische Bevölkerung in der Sowjetunion 1941-1944 (Munich, Oldenbourg, 2008), pp. 201ff, 243ff.

2 'Memorriyalny kompleks rasstrelyannym evrejam' in Kamenka, Bobruisk, Belarus. See the Memorials database, 'Memorial to the Murdered Jews of Europe', Berlin. URL: http://www.memorialmuseums.org/denkmaeler/view/320/ 


\section{Therkel Stræde}

Denkmal-f\%C3\%BCr-die-ermordeten-Juden-des-Bobruisker-Ghettos-im-DorfKamenka (accessed 28 December 2012).

3 See 'Yad Vashem: The untold stories. The murder sites of the Jews in the occupied territories of the former USSR: Bobruysk, Kamenka'. URL: http://www1. yadvashem.org/untoldstories/database/murderSite.asp?site_id=413 (accessed 28 December 2012); and 'Bobruysk, Commemoration of Jewish victims'. URL: http:// www1.yadvashem.org/untoldstories/database/commemoration. asp?cid=344 (accessed 28 December 2012); 'Tragediya i podvig', unpublished memorial album presented to Meïr Zeliger by his daughter, Yad Vashem FA-295.

4 'Memorriyalny kompleks rasstrelyannym evrejam', in Kamenka, Bobruisk, Belarus. Memorials database, 'Memorial to the Murdered Jews of Europe'. URL: http://www.memorialmuseums.org/denkmaeler/view/320/Denkmal-f\%C3\%BCrdie-ermordeten-Juden-des-Bobruisker-Ghettos-im-Dorf-Kamenka (accessed 28 December 2012).

5 'Tätigkeits- und Lagebericht Nr.8 der Einsatzgruppen der Sicherheitspolizei und des SD in der UdSSR (Berichtszeit v. 1.12-31.12.1941), 19 December 1941', (unknown author) in P. Klein (ed.), Die Einsatzgruppen in der besetzten Sowjetunion 1941/42: Die Tätigkeits- und Lageberichte des Chefs der Sicherheitspolizei und des SD (Berlin, Edition Hentrich, 1997) p. 263-75, 268. English translation in Y. Arad, S. Krakowski, S. Spector (eds), The Einsatzgruppen Reports (New York, Holocaust Library, 1989), p. 263.

6 'Poimyonnoe spiski rasstrelyannykh, poveshennykh, zamychennykh i ugnannykh v nemetskoe rabstvo grazhdan gor. Bobruyska, bobruyskogo I paricheskogo rayonov bobruyskoy oblasti BCCR', State Archive of the Russian Federation, Moscow, 7021-82-2, 240, p. 14, copy in Yad Vashem JM/20000 GARF 7021-82-2. URL: http://www1.yadvashem.org/untoldstories/database/murderSite.asp?site_ $\mathrm{id}=413,31 / 12-2012$ (accessed 30 November 2014).

7 Cf. H. Friedlander, The Origins of Nazi Genocide: From Euthanasia to the Final Solution (Chapel Hill, University of North Carolina Press, 1995).

8 'Poimyonnoe spiski rasstrelyannykh', State Archive of the Russian Federation.

9 Cf. T. C. Fox, 'The Holocaust under Communism', in D. Stone (ed.), The Historiography of the Holocaust (London, Palgrave Macmillan, 2004), pp. 420-39.

10 Slutski, Bobroysk, p. 214; and S. Spector \& G. Wigoder (eds), The Encyclopedia of Jewish Life Before and During the Holocaust: Vol.1 (Jerusalem, Yad Vashem, 2001), p. 159f; Imbachkau, Pamyat' Babruysk, p. 433.

11 Klein, 'Tätigkeits- und Lagebericht'. See also footnote 5.

12 Proceedings against members of the Field airport Bobruisk, Central Office of the State Justice Administration, Ludwigsburg II 202 AR-Z 64/60; the erroneous dating of the operation by Gerlach, Kalkulierte Morde, p. 609 is due to unclear passages in the source; D. Romanovskij, 'Skol'ko evreev pogiblo $\mathrm{v}$ promyshlennykh gorodakh vostochnoy Belorussii v nachalene nemetskoy okkupatsii (Iyul'-dekabr 1941)', Vestnik evreyskogo universiteta, 22:4 (2000), 151-72, 158.

13 Cf. A.B. Rossino, Hitler Strikes Poland. Blitzkrieg, Ideology, and Atrocity (Kansas, 
Universty of Kansas Press, 2003); J. Böhler, Auftakt zum Vernichtungskrieg: Die Wehrmacht in Polen 1939 (Frankfurt, Fischer, 2006).

14 For examples of the similar mechanism at work in Eastern Poland, cf. D. Silberklang, Gates of Tears: The Holocaust in the Lublin Region (Jerusalem, Yad Vashem, 2013), pp. 281ff.

15 Cf. H. Krausnick, Hitlers Einsatzgruppen: Die Truppen des Weltanschauungskrieges 1938-1942 (Frankfurt, Fischer, 1985); S. Klemp, 'Nicht ermittelt': Polizeibataillone und die Nachkriegsjustiz - ein Handbuch (Essen, Klartext, 2005).

16 Heeresgruppe Mitte, Propaganda-Einsatz, Bericht v. 11/8-41, Anlage zum Abwehr-Bericht v. 18/9-41, Bundesarchiv-Militärarchiv Freiburg RW 4/vol.252, p. 252; D. Pohl, Die Herrschaft, p. 245; 'Reinhard Heydrich an Einsatzgruppenleiter', Bundesarchiv Babelsberg, 29/6 \& 1/7-41, R70 SU/32; R. Gerwarth, Reinhard Heydrich: Biographie (trans. U. Rennert) (Munich, Siedler, 2011) p. $238 f$.

17 Cf. C. R. Browning, 'The Decision-Making Process', in D. Stone (ed.), The Historiography of the Holocaust (London, Palgrave Macmillan, 2004), p. 173-96; P. Longerich, Der ungeschriebene Befehl. Hitler und der Weg zur 'Endlösung' (Munich, Piper, 2001).

18 Witness statement 24 April 1959 by Reinhold Grabow, then Wehrmacht Oberstleutnant and Wirtschaftsführer in the Bobruisk area German administration (with errors as to the date of the event and the number of victims), Office of the State Justice Administration, Ludwigsburg 202 AR-Z 52/59 Vol. IV, p. 368f; W. Dressen, E. Klee \& V. Riess (eds), 'Schöne Zeiten': Judenmord aus der Sicht der Täter und Gaffer (Frankfurt, Fischer, 1988), p. 118.

19 Cf. P. Longerich, Heinrich Himmler: Biographie (Munich, Siedler, 2008), p. 565f; P. Longerich, Politik der Vernichtung: Die Gesamtdarstellung der nationalsozialistischen Judenverfolgung (Munich, Piper, 1998), p. 371.

20 Cf. Gerlach, Kalkulierte Morde; G. Morsch \& B. Perz, Neue Studien zu nationalsozialistischen Massentötungen durch Giftgas: Historische Bedeutung, technische Entwicklung, revisionistische Leugnung (Berlin, Metropol, 2011); D. Dwork \& R. J. van Pelt, Auschwitz: 1270 to the Present (New York, Norton, 1996).

21 As we know from survivors' testimony, the information by Klemp that the Germans used the same killing method in Bobruisk as in Mogiljov is not correct. Cf. Klemp, 'Nicht Ermittelt', p. 82; Longerich, Politik der Vernichtung, p. 371; Romanovskij, 'Skol'ko evreev pogiblo'.

22 Hartmann, Wehrmacht im Ostkrieg, p. 693; See J. KriegsgefangenenBezirkskommandant, 'Report on the visit to the gulags' (Bericht über die Besichtigung des Dulags), Bundesarchiv-Militärarchiv Freiburg, RH 23/251, 131, 23/7-41; Gerlach, Kalkulierte Morde, p. 802; 'Sudebnyy protsess po dely o zlodeyaniyakh sovershennykh nemetsko-fashistskikh zakhvachikami v Belarusskoy SSR', report from Minsk, 1947; Cf. M. Zeidler, 'Der Minsker Kriegsverbrecherprozess vom Januar 1946: Kritische Anmerkungen zu einem sowjetischen Schauprozess gegen deutsche Kriegsgefangene' in Vierteljahrshefte für Zeitgeschichte, 52:4 (2004), 211-44.

23 Yad Vashem Photo Archive 143B03. 


\section{Therkel Stræde}

24 See 'Oberkommando der Wehrmacht: Anordnung zur Behandlung sowjetischer Kr. Gef. in allen Kriegsgefangenenlagern, 8/9-1941' in G. Ueberschär \& W. Wette (eds), 'Unternehmen Barbarossa': Der deutsche Überfall auf die Sowjetunion: Berichte, Analysen, Dokumente (Paderborn, Schöningh, 1984), p. 351-4.

25 Yad Vashem Photo Archive 143B04.

26 Yad Vashem Photo Archive 143B02.

27 Cf. C. Streit, Keine Kameraden. Die Wehrmacht und die sowjetischen Kriegsgefangenen 1941-1945 (Bonn, Dietz, 1991).

28 Cf. testimony of Yosef Kogan, born 1929, regarding his experiences during his escape from a killing pit and hiding in villages and forests (Yad Vashem Archive O.3 File No. 7813 Item No. 3562331).

29 'Poimyonnoe spiski rasstrelyannykh', State Archive of the Russian Federation.

30 J. Hoffmann, 'Das kann man nicht erzählen': 'Aktion 1005' - Wie die Nazis die Spuren ihrer Massenmorde in Osteuropa Beseitigten (Hamburg, Konkret, 2008), p. $139 \mathrm{ff}$.

31 Cf. Y. Gutman (ed.), Enzyklopädie des Holocaust: Die Verfolgung und Ermordung der europäischen Juden Bd.1 (Munich, Piper, 1995), p. 180.

32 S. Spector, “Aktion 1005”: Effacing the Murder of Millions', in Holocaust \& Genocide Studies, 5:2 (1990), p. 157-73.

33 Ibid. Testimony of 'Aktion 1005' survivor S. Piliunov.

34 L. Weliczker-Wells, The Janowska Road (New York, Macmillan, 1963), p. 149.

35 'Tragediya i podvig', Yad Vashem FA-295.

36 Yad Vashem Photo Archive 7563 Album FA372/6.

37 Maria Mints, a witness from Bobruysk, at the memorial site in Kamenka. (Interview in Yiddish, Hebrew subtitles in the documentary Embers - An Encounter with Soviet Jewry, Summer 1990 (Israel, 1990) Series Director \& Editor: Chaim Yavin, IBA film archive, Channel 1, Yad Vashem, The Visual Center V381. For more information, URL: http://www1.yadvashem.org/untoldstories/database/ murderSite.asp?site_id=413 (accessed 30 September 2014). 